\title{
Anatomy of a Free Speech Lawsuit: Demers against Washington State University (2014)
}

\author{
Christy Hutchison \\ Peru State College
}

\begin{abstract}
Author Note
The author presented orally a portion of this manuscript at the 2016 Institute of Behavioral and Applied Management (IBAM) Conference in San Diego, California.
\end{abstract}

\begin{abstract}
The 2006 U.S. Supreme Court case of Garcetti v. Ceballos eliminated First Amendment free speech rights of public employees when they speak or write as a part of their jobs. The decision jolted the academic community, as it was not clear whether the high Court intended for the Garcetti principle to apply to public university faculty who necessarily speak and write as an integral part of their duties to teach and publish. This paper analyzes the 2014 appellate case of Demers against Washington State University and discusses the free speech rights of public university faculty.
\end{abstract}

Keywords: Free Speech, Academic Freedom, First Amendment

\section{Introduction: The Case of Demers against Washington State University}

David Demers was a member of the faculty in the Edward R. Murrow College of Communication at Washington State University (WSU) in 2007 when the events giving rise to his lawsuit occurred. Demers joined the WSU faculty in 1996 and earned tenure as an associate professor three years later. He also owned and operated an independent publishing company known as Marquette Books (Demers v. Austin, 2014).

In 2006, the WSU Edward R. Murrow College of Communication (Murrow College) was under review for reorganization. Murrow College faculty and officials were considering breaking away from the College of Liberal Arts and dividing the faculty into two separate entities - one for mass communications and one for communications studies. There was serious disagreement among faculty about this proposal. The College convened a Structure Committee to review the options and make a recommendation about a new structure for Murrow College. David Demers was a member of the Structure Committee (Demers v. Austin, 2014). 
In late 2006, Demers prepared a two-page pamphlet titled "The 7-Step Plan" (the Plan) which set forth his proposal for reorganizing and revitalizing the mass communication programs of Murrow College. Demers drafted and distributed the pamphlet on his own and not as a part of his work on the Structure Committee.

In January 2007, Demers sent his Plan to the Provost of WSU. In his cover letter, he stated that the purpose of the Plan was to show how WSU “... can turn the Edward R. Murrow School of Communication into a revenue-generating center for the university and, at the same time, improve the quality of the program itself" (Demers v. Austin, 2014). Demers' letter also stated, "To initiate a fund-raising campaign to achieve this goal, my company and I would like to donate $\$ 50,000$ in unrestricted funds to the university." Demers signed the letter "Dr. David Demers, Publisher/ Marquette Books LLC." He included a footnote that read, "Demers also is associate professor of communications at Washington State University. Marquette Books LLC is a book/journal publishing company that he operates in his spare time. It has no ties with nor does it use any of the resources at Washington State University." In March, Demers sent the Plan to the President of WSU. The cover letter was identical to the letter he had sent to the Provost, except that he increased the offered donation to $\$ 100,000$ (Demers v. Austin, 2014).

Demers claimed that he also sent the Plan to members of the print and broadcast media, to administrators at WSU, to some of his colleagues, to the Murrow Professional Advisory Board, and others. He posted the Plan on the Marquette Books website. Notably, Demers did not submit the Plan to the Structure Committee or to Interim Director of Murrow College, Erica Austin. Austin testified that alumni and members of the professional community contacted faculty members to ask about the Plan (Demers v. Austin, 2014).

Demers alleged that WSU and certain University officials including Interim Director Erica Austin, Vice Provost for Faculty Affairs Frances McSweeney, Dean of the College of Liberal Arts Erich Lear, and Interim WSU Provost and Executive Vice President Warwick Bayly, retaliated against him for writing and distributing the Plan. He claims that the Plan was protected First Amendment free speech and that the retaliation he suffered was in violation of his constitutional rights (Demers v. Austin, 2014).

In 2007, Demers distributed a second document titled "The Ivory Tower of Babel” (Ivory Tower), which was a draft introduction and draft chapters of a book he was authoring. Demers claimed that this book would be "critical of the academy, including some events at Washington State University." He included descriptions of the book in his self-prepared 2006 Annual Activity Report and in an application for a sabbatical leave that he requested in late 2007. Demers did not submit the book to the court, so only brief descriptions contained in other documents were available to the court and it ultimately held that there was insufficient evidence for a claim of retaliation based on the book Ivory Tower (Demers v. Austin, 2014).

Demers filed suit in 2009, claiming that WSU officials retaliated against him because of his two documents - the Plan and his book Ivory Tower. He alleged that University officials gave him negative annual performance reviews that contained falsehoods, that they conducted two internal audits, and that they entered a formal notice of discipline against him. Demers further asserted that Austin and others knowingly used incorrect information to lower his performance 
review scores for 2006, 2007, and 2008. He said that some officials falsely stated that he had improperly canceled classes and that he had not gone through the proper university approval process before starting Marquette Books. He accused officials of spying on his classes, preventing him from serving on certain committees, preventing him from teaching basic communications courses, and excluding him from heading the journalism course sequence at Murrow College. Demers said that these acts affected his compensation and his reputation as an academic. He claims that over a three-year period he "went from being a popular teacher and scholar with high evaluations to a target for termination" due to the actions of the WSU officials named in his lawsuit (Demers v. Austin, 2014).

In their defense, WSU officials contended that changes in Demers' evaluations and the investigations by the university were warranted, and were not retaliation for the Plan or Ivory Tower. The officials stated that Demers reoriented his priorities away from academia after receiving tenure, that his attendance at faculty committee meetings was sporadic, and that he gave online quizzes instead of appearing in person to teach his Friday classes as required by university policy (Demers v. Austin, 2014). They asserted that the legitimate reasons for negative annual reviews of Demers included his post-tenure failure to publish scholarship in refereed journals, his failure to perform his appropriate share of university service, and his failure to report properly his activities at Marquette Books. They also explained that Demers' lower marks under Interim Director Austin were partly attributable to an overall adjustment of the annual review scale for the faculty as a whole (Demers v. Austin, 2014).

\section{Background: The Origin of Academic Freedom}

The U.S. Supreme Court first recognized that a university has a special right to independence from state control in the case of Sweezy v. New Hampshire, 354 U.S. 234 (1957). Justice Felix Frankfurter observed that a university should "determine for itself on academic grounds who may teach, what may be taught, how it shall be taught, and who may be admitted to study" (Sweezy v. New Hampshire, 1957) (Frankfurter, J., concurring).

In 1967, the U.S. Supreme Court first used the term academic freedom and identified it as a "special concern" of the First Amendment to the Constitution. In Keyishian v. Board of Regents, 385 U.S. 589, 603 (1967) Justice William Brennan, writing for the Court stated, "Our Nation is deeply committed to safeguarding academic freedom, which is of transcendent value to all of us, and not merely to the teachers concerned. That freedom is therefore a special concern of the First Amendment, which does not tolerate laws that cast a pall of orthodoxy over the classroom.... The Nation's future depends upon leaders trained through wide exposure to that robust exchange of ideas which discovers truth 'out of a multitude of tongues, [rather] than through any kind of authoritative selection"' (Keyishian v. Board of Regents, 1967).

As recently as 2003, the Court referred back to the Keyishian case as the proper formulation of the term academic freedom (Grutter v. Bollinger, 2003). There is no dispute that the concept of academic freedom is rooted in constitutional freedom of speech found in the First Amendment to the U.S. Constitution. More recently, the question has become whether or not academic freedom may exist independent of the right to freedom of speech. Even when there is determined to be no freedom of speech rights for the job-related statements of a public employee 
generally, might there still be an independent constitutional interest known as academic freedom that is applicable to publicly employed professors? This is the issue raised but not resolved in the 2006 case of Garcetti v. Ceballos, 547 U.S. 410 (2006).

\section{Public Employee Free Speech: Pickering v. Board of Education (1968)}

Since 1968, workplace freedom of speech for public employees, including faculty members employed by public colleges and universities, has been governed by the 1968 U.S. Supreme Court case of Pickering v. Board of Ed. of Township High School Dist. 205, Will Cty., 391 U. S. 563 (1968). Marvin Pickering was a public high school teacher in Will County, Illinois, in 1961. Pickering opposed a school bond issue that had recently been the subject of a public vote, and he wrote about his opposition to the local newspaper. Pickering's letter contained statements, widely viewed as false, criticizing the school board's allocation of school funds between educational and athletic priorities and accusing board members of trying to misinform the public about the intended use of the proposed new tax revenues (Pickering $v$. Board of Ed., 1968).

In considering Pickering's claim of protected speech, the U.S. Supreme Court observed the need to "arrive at a balance between the interests of the teacher, as a citizen, in commenting upon matters of public concern and the interest of the State, as an employer, in promoting the efficiency of the public services it performs through its employees" (Pickering v. Board of Ed., 1968). The resulting product of this consideration is the two-prong test that became known as the Pickering Balancing Test.

Under the first prong of the Pickering Balancing Test, the Court considers whether a speaker who is both a citizen and a public employee, has expressed himself (a) as an employee, about a private employment matter, or (b) as a citizen, on a matter of public concern. If the answer to this question is the former - that the person spoke as an employee about a private employment matter - then the First Amendment does not provide protection and the analysis is over. If the answer is the latter, that the person spoke as a citizen on a matter of public concern, then the analysis moves to the second prong of the test.

Under the second prong of the Pickering Balancing Test, the Court balances the interests of the employee, as a citizen, in commenting on matters of public concern, against the interests of the government, as an employer, in promoting the efficiency of the operations and public services it performs through its employees (Pickering v. Board of Ed., 1968). Noting that Marvin Pickering's speech neither impeded his performance in the classroom, nor interfered with the regular operations of the school, the Court concluded that the school administration had little legitimate interest in controlling Marvin Pickering's speech. Indeed, the school had no greater interest in limiting Pickering's speech than it had in limiting the speech of any member of the public.

On the other side of the scale was Pickering's right to comment on issues of public importance and the public's right to hear free and uninhibited debate on matters of public concern. After a discussion of the interests on both sides of the scale, the Court decided that 
Pickering's interest in speaking outweighed the school board's interest in limiting a teacher's speech in order to promote the efficiency of its operations (Pickering v. Board of Ed., 1968).

For the next 38 years, federal and state courts applied the Pickering Balancing Test to cases involving many types of public employees, including teachers (Mt. Healthy City School District Board of Education v. Doyle, 1977) government attorneys (Connick v. Myers, 1983), clerical employees (Rankin v. McPherson, 1987), and others (Schoen, 1999; Smith, 1990).

\section{Garcetti v. Ceballos (2006): A Significant Limitation of Free Speech Rights}

On May 30, 2006, the U.S. Supreme Court issued a controversial 5-4 decision holding that public employees' statements are not entitled to First Amendment protection when made pursuant to their official duties. In Garcetti v. Ceballos, 547 U.S. 410 (2006), a case pertaining to the statements of a public district attorney, the Court held that when public employees make statements pursuant to their official duties, the employees are not speaking as citizens for First Amendment purposes, and the Constitution does not protect their communications from employer discipline.

With this, the high Court jolted the otherwise tranquil body of law relating to public workplace freedom of speech and raised questions about the applicability of the new rule to publicly employed professors when they teach and write in the course of their employment. Under the Garcetti ruling, the expressions of a public employee that are made pursuant to his or her job duties will always fail the first prong of Pickering and will always be a proper subject for employer restriction or discipline. This is true even when the speech involves a matter of public concern, about which citizens generally are allowed unfettered speech.

\section{The Dissent in Garcetti: What About Academic Freedom?}

The Garcetti case spawned dissenting opinions written by Associate Justices Stevens, Breyer and Souter. Justice Souter, whose opinion was the most expansive of the dissents, raised the specter that the majority's view of the case might have an adverse effect on established principles of academic freedom and free speech rights of college professors. Souter noted that professors in public colleges and universities necessarily teach, speak and write pursuant to their official duties. If the holding in Garcetti means that the Fourth Amendment does not protect the work of professors when they teach, perform research and publish, then the case essentially nullifies academic freedom in public colleges and universities. The First Amendment would no longer protect the speech or publications of professors from regulation by their public employers. In extreme cases, an institution might lawfully discipline or terminate a professor for speech that it finds to be unfavorable to the institution.

Fortunately, the majority opinion in the Garcetti case left open the question of its applicability to college professors. Responding to Justice Souter's concern, the majority allowed for the possibility of an exception for public college and university professors, stating, "There is some argument that expression relating to academic scholarship or classroom instruction implicates additional constitutional interests that are not fully accounted for by this Court's customary employee speech jurisprudence. We need not, and for that reason do not, decide 
whether the analysis we conduct today would apply in the same manner to a case involving speech related to scholarship or teaching" (Garcetti v. Ceballos, 2006).

While members of the academy breathed a collective sigh of relief, this was hardly a bold affirmation of academic freedom principles. The fact remains that public college and university professors are public employees, and some of them speak and write daily on matters that may offend their government employers. For the moment, these statements appeared to be beyond the reach of Garcetti. However, the majority of the Court declined to say this would always be true (Garcetti v. Ceballos, 2006).

\section{Post-Garcetti Cases: Mixed Results}

Since the Garcetti ruling in 2006, trial and appellate level courts have been forced to decide on the breadth and extent of the Garcetti principle, and whether or not (and how) it should be applied to professors who speak, write, and publish in their disciplines while also serving as employees of public colleges and universities. The results of these cases have been mixed, suggesting that the application of the Garcetti principle to public institution faculty members is not yet settled law. The following two cases illustrate opposing positions on the application of Garcetti.

By far the most enthusiastic support for faculty free speech in the post-Garcetti era comes from the US Circuit Court of Appeals for the Fourth Circuit and arises out of the University of North Carolina-Wilmington (UNCW). Issued on April 6, 2011, the decision of Adams v. University of North Carolina-Wilmington, 640 F.3d 550 (4th Cir. 2011) fully endorses the principle that Garcetti should not apply in the academic context of a public university based on the clear reservation set forth by the US Supreme Court in the majority Garcetti opinion.

The lower district court trial judge in Michael Adams' lawsuit against the University of North Carolina-Wilmington had ruled that Garcetti applied to the speeches and writings of Adams because Adams listed his speeches and publications in his application for promotion from Associate Professor to Professor (Adams v. University of North Carolina-Wilmington, 2011). Essentially, the trial judge held that Adams' otherwise protected speech was converted into unprotected job-related speech under Garcetti because Adams cited it in his application for promotion. According to the trial judge, the inclusion of a publication in an application for promotion made the document "speech pursuant to the official duties" of the faculty member and resulted in it being subject to possible adverse action by the professor's employer (Adams $v$. University of North Carolina-Wilmington, 2011). If adopted as a majority view, this position would allow a college or university to discipline or terminate any professor for any speech with which it disagreed if the speech was included in a faculty members' application for promotion. Many in the academic and legal communities believed this to be a dangerously low bar for determining the applicability of Garcetti to the speech of college faculty.

Fortunately, on appeal, the U.S. Fourth Circuit Court of Appeals discussed the Garcetti case and held that the district court had erred in its interpretation of Garcetti. The Fourth Circuit discussed at length the meaning of the reservation language in Garcetti and why Garcetti should not apply to the work of professors in a public academic institution. The Fourth Circuit held that the district court misinterpreted Adams' role in relation to the speech, noting that, "Nothing 
about listing the speech on Adams' promotion application changed Adams' status when he spoke or the content of the speech when made" (Adams v. University of North Carolina-Wilmington, 2011).

The Fourth Circuit recognized that courts should only rarely apply Garcetti to the work of faculty members in a public institution, and the narrow range of applicability was not present in this case. The court stated, "There may be instances in which a public university faculty member's assigned duties include a specific role in declaring or administering university policy, as opposed to scholarship or teaching. In that circumstance, Garcetti may apply to the specific instances of the faculty member's speech carrying out those duties" (Adams v. University of North Carolina-Wilmington, 2011). Beyond that circumstance, the court found no basis for applying Garcetti to the work of a faculty member. The court concluded, 'Put simply, Adams' speech was not tied to any more specific or direct employee duty than the general concept that professors will engage in writing, public appearances, and service within their respective fields. For all the reasons discussed above, that thin thread is insufficient to render Adams' speech "pursuant to [his] official duties" as intended by Garcetti" (Adams v. University of North Carolina-Wilmington, 2011).

One year after the Adams decision, the U.S. Sixth Circuit Court of Appeals issued a conflicting ruling, holding that Garcetti applies to some speech of faculty members when they serve on institutional committees and interact with other faculty and administrators on campus. In Savage v. Gee, 665 F.3d 732 (6th Cir. 2012), the Sixth Circuit held that Scott Savage, who was the Head of Reference and Library Instruction at The Ohio State University (OSU), was not entitled to First Amendment protection of his speech made with reference to his work on a university committee.

From August 2004 until his resignation in 2007, Savage assisted OSU faculty and students with research, helped prepare course bibliographies, and taught students research methods. In February 2006, Savage joined a committee tasked with choosing a book for assigned reading for all incoming freshmen. Other members of the committee included faculty members and the Student Affairs Director. After several committee members recommended books that the litigants characterized as "liberal," Savage proposed the book Freakonomics by Steven Levitt and Stephen Dubner. Then followed a number of contentious emails about various book choices resulting in an accusation made by another committee member against Savage stating that his book choices were "bigoted" and "homophobic" and questioning Savage's competence and professionalism as a librarian. Savage responded in an e-mail to the committee: "[I]f we are decided that we want to engage our students in the kind of exchange of ideas on which the 'secular' university is founded, then let's choose something that confronts the accepted wisdom of Ohio State University! Like students and young profs did in the 60's, man!" His e-mail listed four book titles, providing a short description of each book. One of the books, The Marketing of Evil by David Kupelian, contains a chapter describing homosexuality as aberrant human behavior (Savage v. Gee, 2012).

The dustup escalated into formal cross-grievances for harassment and eventually to Savage taking a leave of absence from his job due to extreme emotional distress. Finally, Savage resigned his position and filed suit against OSU and several university officials alleging, among 
other things, that the university had constructively discharged him in retaliation for constitutionally protected speech. Savage asserted that his speech related to academic scholarship or classroom instruction and that it should therefore be exempt from the traditional First Amendment analysis applied to public employees. In other words, even though Savage's speech arose in the course of his job as a public employee, it should nonetheless be protected from the application of the Garcetti rule. The Sixth Circuit disagreed (Savage v. Gee, 2012). In analyzing Savage's speech, the Sixth Circuit opined that

Savage's speech as a committee member commenting on a book recommendation was not related to classroom instruction and was only loosely, if at all, related to academic scholarship. Thus, even assuming Garcetti may apply differently, or not at all, in some academic settings, we find that Savage's speech does not fall within the realm of speech that might fall outside of Garcetti's reach. (Savage v. Gee, 2012)

The court further concluded that Savage failed to present any evidence of an adverse employment action by OSU, so even aside from the First Amendment ruling, Savage would not have prevailed on his claim. These two opposing rulings from the U.S. Fourth and Sixth Circuit Courts of Appeal respectively - Adams v. University of North Carolina-Wilmington in 2011 and Savage v. Gee in 2012 - illustrate the unsettled state of the law when Demers filed his lawsuit in the U.S. Ninth Circuit Court of Appeals against the officials of Washington State University.

\section{The Demers Decision: No Violation of Demers' Free Speech Rights}

Decided in 2014 by the U.S. Ninth Circuit Court of Appeals, the Demers case is a study in the many ways that a faculty member might lose a First Amendment academic freedom case against a public institution. While the Ninth Circuit decided several important legal arguments in favor of Demers and faculty free speech generally, Demers still lost the case on two other bases. First, the court held that there was insufficient evidence of retaliation by university officials. Second, the court held that the officials were entitled to qualified immunity (relief from legal responsibility) given the uncertain state of the law in the wake of Garcetti (Demers v. Austin, 2014).

The best news to come out of the Demers case is the holding that the Garcetti principle -that public employees have no free speech rights when speaking pursuant to their official duties - was determined not to apply to faculty members' speech related to scholarship or teaching. Demers' first argument was that his speech in the form of the two-page pamphlet titled "The 7Step Plan" (the Plan) which set forth his proposal for reorganizing and revitalizing the mass communication programs of Murrow College was not done pursuant to his official duties as an employee of the university. Demers claims that he drafted and published the Plan as an employee of Marquette Books. The court rejected this notion on two grounds: first, that Demers was serving on the Murrow College Structure Committee, which was working on exactly the issue that Demers addressed in the Plan, and second, that Demers noted the Plan as an achievement in his self-prepared 2007 Annual Activity Report (Demers v. Austin, 2014). Despite Demers' claim to the contrary, the court stated: 
But we conclude that in preparing the Plan, in sending the Plan to the Provost and President, in posting the Plan on the Internet, and in distributing the Plan to news media, to selected faculty members and to alumni, Demers was acting sufficiently in his capacity as a professor at WSU that he was acting "pursuant to [his] official duties" within the meaning of Garcetti. (Demers v. Austin, 2014)

It is important to note that Demers explicitly stated that his authorship of the Plan was his work as an employee of Marquette Books, and not as a faculty member or member of the Structure Committee. Demers signed his cover letter "Dr. David Demers, Publisher/ Marquette Books LLC" and he included an offer for a private donation to the university. He added by footnote, "Demers also is associate professor of communications at Washington State University. Marquette Books LLC is a book/journal publishing company that he operates in his spare time. It has no ties with nor does it use any of the resources at Washington State University" (Demers $v$. Austin, 2014). Despite this, the court found that Demers wrote the Plan pursuant to his official duties as a faculty member. It would appear that the court was persuaded by the similarity of the subject of the Plan to Demers' work on the Structure Committee and by his inclusion of the Plan in his annual activity report. (Note that the Fourth Circuit Court in the Adams case, discussed above, rejected a similar argument.)

Demers' second argument was that even if the court viewed his authorship of the Plan as work pursuant to his official duties as a faculty member, the court should declare it to be academic writing and not subject to the Garcetti principle. With this, the Ninth Circuit agreed, holding that the Plan was academic in nature. The court stated, "We conclude that if applied to teaching and academic writing, Garcetti would directly conflict with the important First Amendment values previously articulated by the Supreme Court." Interestingly, even though the Ninth Circuit disagreed with the Fourth Circuit on the matter of including a publication in an annual activity report as a basis for determining speech to be job-related, the Ninth Circuit cited the Adams decision favorably as support for its rationale that Garcetti should not apply to Demers' speech anyway. In this way, the Ninth Circuit both rejected and accepted parts of the Fourth Circuit's decision in Adams (Demers v. Austin, 2014).

A further important holding in the Demers case is the application of the Pickering Balancing Test to Demers' speech. Having rejected the application of Garcetti, the Ninth Circuit stated that the proper test to be applied to the speech of faculty members is the 1968 Pickering Balancing Test. Applying this test, the court first looked at the question of whether the speech addressed matters of public concern as opposed to personal interest. It noted that public concern is a broad concept and determined that the future of the Edward R. Murrow College of Communication is an important matter about which the public clearly is or should be concerned. Unlike a matter of personal interest or private grievance, the structure of Murrow College is a public matter. Demers' proposal, if implemented, would have substantially altered the nature of what was taught at the school, as well as the composition of the faculty that would teach it (Demers v. Austin, 2014). Being a public matter, this issue moves to the second question of the Pickering Balancing Test - the balancing of the interests of the employee, as a citizen, in commenting upon matters of public concern and the interests of the State, as an employer, in promoting the efficiency of the public services it performs through its employees. The Ninth Circuit sidestepped this issue and determined that this was a question of fact to be remanded to 
the trial judge for further consideration of the evidence. Essentially, the Ninth Circuit refrained from deciding this issue and sent it back to the trial court for a fact-based ruling.

Another important ruling of the court was on Demers' claim of retaliation, in response to his circulation of the Plan and his book Ivory Tower. Demers claimed that Austin and others knowingly used incorrect information to lower his performance review scores for 2006, 2007, and 2008. He accused some officials of falsely stated that he had improperly canceled classes and that he had not gone through the proper university approval process before starting Marquette Books. Demers stated that specific acts of retaliation included spying on his classes, preventing him from serving on certain committees, preventing him from teaching basic Communications courses, instigating two internal audits, sending him an official disciplinary warning, and excluding him from heading the journalism course sequence at the Murrow School. He claimed that these acts affected his compensation and his reputation as an academic (Demers v. Austin, 2014).

University officials explained that changes in Demers' evaluations and the investigations by the university were warranted, and were not retaliation for the Plan or Ivory Tower. They contended that he reoriented his priorities away from academia after receiving tenure, that his attendance at faculty committee meetings was sporadic, and that he gave online quizzes instead of appearing in person to teach his Friday classes as required by university policy. University officials said Demers failed to publish scholarship in refereed journals, failed to perform his appropriate share of university service, and failed to report properly his activities at Marquette Books. They also stated that Demers' lower marks under Interim Director Austin were partly attributable to an overall adjustment of the annual review scale for the faculty as a whole (Demers v. Austin, 2014). Noting the factual nature of the accusations, the Ninth Circuit remanded the question back to the trial court. It ordered the trial court to determine if Demers' circulation of the Plan was a substantial or motivating factor in any adverse employment action the university officials might have taken, and if they would have taken such employment action absent the protected speech (Demers v. Austin, 2014).

The final significant ruling in Demers was on the issue of the university officials' claim for qualified immunity. Public officials are entitled to qualified immunity from legal responsibility if they reasonably could have believed that their conduct was lawful "in light of clearly established law and the information [that they] possessed" (Demers v. Austin, 2014). This is true even if they violated an individual's First Amendment rights. In this case, the relevant question is whether or not the law regarding Garcetti and its application (or not) to the speech of faculty members was clearly established at the time that the university officials took the action which was alleged to be retaliation. The law is "clearly established" when a reasonable official would have understood that what he was doing violated the constitutional rights of another. The Ninth Circuit held that because there was no Ninth Circuit law on point to inform officials about whether or how Garcetti might apply to a professor's academic speech, the university officials were entitled to qualified immunity (Demers v. Austin, 2014). Thus, Demers would not be able to obtain a judgment against the officials for violating his First Amendment rights. 


\section{Conclusion: Don't Bet Your Future on Winning a Free Speech Case}

David Demers' case against Washington State University officials provides an instructive lesson on the complexity of a free speech case and the difficulties one might encounter in trying to win such a case against a university. Despite the strength of the facts on a professor's side, there are many pitfalls that one might encounter. The following is a listing of ways that a free speech case can go awry.

1. The court might determine that the Garcetti principle - that public employees have no free speech rights when speaking pursuant to their official duties - applies to faculty members who are employees of public college or universities. Since the law is unsettled on this question, U.S. Circuit Courts of Appeal may well decide that Garcetti applies to faculty members' speech and publications. In this case, the professor will lose the case before he or she even gets out of the starting gate. Until the U.S. Supreme Court rules on this question explicitly, lower courts are free to apply Garcetti to faculty members. When a court applies Garcetti to faculty, the only argument left is that the speech at issue was not job-related but was private speech not made "pursuant to official duties." This will be a difficult argument to win, especially if the speech pertains to the professor's discipline and he or she includes it in an annual performance report.

2. Even if Garcetti is deemed not to apply, the professor might be tripped up by the 1968 Pickering Balancing Test. Under Pickering, the faculty member must be able to convince the court that the speech in question was on a matter of public concern (not a private grievance), and that the interest of the faculty member in speaking outweighs the interests of the institution in promoting the efficiency of the public services it performs through its employees. Failing on either one or both of these points will cause the professor to lose the case.

3. Another potential obstacle for a complaining professor is the matter of retaliation and the cause for it. If the professor cannot provide proof of specific acts of retaliation or cannot convince the court that officials intended to retaliate for the speech in question, then the professor might lose the case. The court might decide that there was no retaliation or that the adverse treatment of the professor arose from another cause apart from the professor's speech. In either circumstance, the professor will lose.

4. Finally, the professor could win on every issue cited above and prove that university officials intentionally retaliated against him or her for protected speech, and yet still lose the case on the basis that the acting officials are entitled to qualified immunity. Officials might be entitled to immunity (relief from legal responsibility) for their wrongful acts if they can show that the state of the law was uncertain at the time of their actions (for example, the applicability of Garcetti was not clear) and that they believed their conduct was lawful in light of the information they possessed. Given the uncertain nature of the reach of Garcetti, this argument will be viable protection for university officials until each of the U.S. Circuit Courts of Appeal have ruled on the 
applicability of Garcetti to the speech of public college and university faculty members, or until the U.S. Supreme Court decides the question.

While court watchers and legal scholars might enjoy reading and analyzing these cases for years to come, potential litigants would be smart to exercise caution and to think carefully before embarking on a lawsuit against a public institution for a claimed violation of academic freedom and free speech rights.

\section{References}

Adams v. University of North Carolina-Wilmington, 640 F.3d 550 (4th Cir. 2011).

Connick v. Myers, 461 U.S. 138 (1983).

Demers v. Austin, 746 F.3d 402 (9th Cir. 2014).

Garcetti v. Ceballos, 547 U.S. 410 (2006).

Grutter v. Bollinger, 539 U.S. 306 (2003).

Keyishian v. Board of Regents, 385 U.S. 589, 603 (1967).

Mt. Healthy City School District Board of Education v. Doyle, 429 U.S. 274 (1977).

Pickering v. Board of Ed. of Township High School Dist. 205, Will Cty., 391 U. S. 563 (1968).

Rankin v. McPherson, 483 U.S. 378 (1987).

Savage v. Gee, 665 F.3d 732 (6th Cir. 2012).

Schoen, R. B. (1999). Pickering plus thirty years: Public employees and free speech. Texas Tech Law Review, 30, 5-30.

Smith, D. G. (1990). Beyond "public concern": New free speech standards for public employees. University of Chicago Law Review, 57, 249-255.

Sweezy v. New Hampshire, 354 U.S. 234 (1957). 